\title{
Exploiting ground-based optical sensing technologies for volcanic gas surveillance
}

\author{
Clive Oppenheimer and Andrew J.S. McGonigle \\ Cambridge Volcanology Group, Department of Geography, University of Cambridge, U.K.
}

\begin{abstract}
Measurements of volcanic gas composition and flux are crucial to probing and understanding a range of magmatic, hydrothermal and atmospheric interactions. The value of optical remote sensing methods has been recognised in this field for more than thirty years but several recent developments promise a new era of volcanic gas surveillance. This could see much higher time- and space-resolved data-sets, sustained at individual volcanoes even during eruptive episodes. We provide here an overview of these optical methods and their application to ground-based volcano monitoring, covering passive and active measurements in the ultraviolet and infrared spectral regions. We hope thereby to promote the use of such devices, and to stimulate development of new optical techniques for volcanological research and monitoring.
\end{abstract}

Key words volcano monitoring - volcano plumes IR and UV spectoscopy

\section{Introduction}

Volcanoes emit gases (principally $\mathrm{H}_{2} \mathrm{O}$, $\mathrm{CO}_{2}, \mathrm{SO}_{2}, \mathrm{HCl}, \mathrm{HF}$ and $\mathrm{H}_{2} \mathrm{~S}$ ) and aerosols to the atmosphere, both during and between eruptions. Measurements of the chemistry, isotopic composition, and flux of these emissions, and their temporal variations are crucial in several applications (Oppenheimer et al., 2003).

\section{1. «Imaging» volcanic plumbing systems and predicting volcanic activity}

Volcanic gas composition and flux relate to subsurface magmatic conditions and higher-level fluid-rock interactions, providing information

Mailing address: Dr. Clive Oppenheimer, Cambridge Volcanology Group, Department of Geography, University of Cambridge, Downing Place, Cambridge, CB2 3EN, U.K.; e-mail: co200@cam.ac.uk on magma composition, volume, storage, and transport. For instance, temporal variations in the ratios of emitted $\mathrm{CO}_{2} / \mathrm{SO}_{2}$ and $\mathrm{HCl} / \mathrm{SO}_{2}$ have been used to infer changes in magmatic systems feeding volcanoes (e.g., Noguchi and Kamiya, 1963; Gerlach and Casadevall, 1986), whilst gas flux measurements have been used to constrain the masses of degassing magmas (Symonds et al., 1996). Such data are valuable for hazard assessment because volcanic activity is strongly controlled by the dynamics of degassing (Sparks, 2003). In the broader context of volcano monitoring efforts, the links between seismic, geodetic and gas geochemical signals can be strong. The degassing process may be closely associated with, even responsible for, observed seismicity and ground deformation.

\subsection{Understanding atmospheric and radiative effects}

Quantification of volcanic volatile emissions is also important in order to evaluate their hemispheric to global scale atmospheric and climatic impacts. The sulfur emissions from major explo- 
sive eruptions can perturb the chemistry, dynamics and radiative transfer in both the troposphere and stratosphere, influencing surface climate (e.g., McCormick et al., 1995). Passively degassing volcano emissions must also influence tropospheric dynamics and chemistry, as recent investigations suggest that between 15 and $40 \%$ of the global tropospheric sulphate burden is volcanogenic (Chin and Jacob, 1996; Graf et al., 1998; Stevenson et al., 2003). These figures exceed the percentage source strength of volcanic sulphur by a factor of 2-4, reflecting the generally higher altitudes of atmospheric entrainment from volcanoes compared with biogenic or anthropogenic sources, and highlighting the importance of better understanding the tropospheric chemistry of volcanic emissions.

\subsection{Evaluation of environmental and health impacts}

From local to regional scales, volcanic emissions can result in serious environmental and environmental health consequences, including destruction of agricultural crops, contamination of pasture, and human respiratory morbidity and cardiovascular mortality. Large lava eruptions, such as that of Laki (Iceland) in $1783 / 1784$, which released $\approx 120 \mathrm{Tg}$ of $\mathrm{SO}_{2}$, 7.0 $\mathrm{Tg}$ of $\mathrm{HCl}$ and $15 \mathrm{Tg}$ of $\mathrm{HF}$, have resulted in major pollution episodes responsible for regional-scale extreme weather, agricultural losses, and elevated human morbidity and mortality (Thordarson et al., 1996; Witham and Oppenheimer, 2004). Individual passively degassing volcanoes can also represent major pollution sources. For example, Mt. Etna continuously emits of order $2 \mathrm{~kg} \mathrm{~s}^{-1}$ of HF, and $>8 \mathrm{~kg} \mathrm{~s}^{-1}$ of $\mathrm{HCl}$ (Francis et al., 1998). Its $\mathrm{SO}_{2}$ flux $(\approx 70$ $\mathrm{kg} \mathrm{s}^{-1}$ ) is comparable to the total industrial $\mathrm{S}$ emission from France, and substantially elevates tropospheric sulphate in southern Italy (Graf et al., 1998). Adverse environmental and health impacts are observed downwind of many degassing volcanoes, including Masaya (Nicaragua), Kĩlauea (Hawai`i), Poás (Costa Rica), Miyakejima (Japan) and Popocatépetl (Mexico) (e.g., Baxter et al., 1982; Mannino et al., 1996; Delmelle, 2003; Fujita et al., 2003).
At Masaya volcano, which has been degassing strongly for over a decade without significant eruption, boundary layer $\mathrm{SO}_{2}$ concentrations are elevated over a downwind area $>1000 \mathrm{~km}^{2}$, resulting in substantial economic impact from the loss of coffee crops, and exposing $\approx 50000$ people to levels exceeding WHO air quality standards (125 ppb over 24 h; 50 ppb over 1 yr). Downwind of Popocatépetl volcano, $\mathrm{SO}_{2}$ quadrupled, and sulphate concentrations doubled in Mexico City when fumigated by the volcanic plume (Raga et al., 1999).

The aims of this paper are to review briefly some of the latest developments in ground based optical sensing of volcanic gas and aerosol emissions. We focus particularly on those instruments that have come to the fore over the last ten years that are capable of augmenting or superseding the Correlation Spectrometer (COSPEC) device, which has seen widespread use over the last thirty years for volcanic $\mathrm{SO}_{2}$ flux measurements. We also discuss the challenges that remain in implementing gas-monitoring networks, and in interpreting their data streams. It is hoped that this article will stimulate development of further optical sensing technologies, characterised by low cost, low maintenance, low weight and bulk, high temporal resolution, and multi-component sensitivity, that will meet key volcanological requirements.

\section{General methodological background and challenges}

The conventional way to measure volcanic emissions is by direct sampling, either by closerange collection of samples from fumarole vents and active lava bodies using «Giggenbach bottles», filter packs and condensing systems, or within atmospheric plumes from aircraft using various kinds of sampling apparatus and onboard analysers. A range of spectroscopic, gravimetric, isotopic and chromatographic techniques is available to determine chemical concentrations in real time or subsequently in the laboratory (Symonds et al., 1994). Whilst direct sampling is capable of delivering very detailed and accurate analyses, it is difficult to sustain routine surveillance in this way, or to 
provide data of sufficient temporal resolution to compare meaningfully with seismic and geodetic data streams. Arguably, the primary reason for this is the risk involved in the field, which generally restricts investigations to low temperature, subordinate vents (that probably do not characterize the bulk emission or represent the parts of the magmatic-hydrothermal system most sensitive to change in the event of renewed magmatic activity). Additionally, chemical reactions between the container material or reagents and the collected gas sample may mask the original chemical composition. Whilst the use of telemetered electrochemical sensors for continuous gas monitoring avoids many of the above complications (McGee and Sutton, 1994), this approach is not yet widespread and it suffers the problem that sensors may be destroyed in the event of an eruption.

In this section, we look at the general background to volcanic gas sensing using optical methods, highlighting some of the key issues in adapting and developing remote sensing instruments for volcanological purposes, and interpreting the data they yield. Much of the discussion applies to volcano monitoring devices in general.

\subsection{Spectroscopy background}

The sensing methods described in section 3 are based on the spectroscopic observation of molecular species of interest from their fingerprint rotational, vibrational and electronic transitions, usually seen in absorption (i.e., the attenuation of a source of radiation behind the gas cloud; fig. 1) but sometimes in emission. Specific gases can be identified by their characteristic absorption spectra, and their abundances derived from the strength of the absorption, following the Beer-Lambert formula:

$$
I(\lambda)=I_{0}(\lambda) \exp (-\sigma(\lambda) N L)
$$

where $I(\lambda)$ is the observed intensity of radiation at wavelength $\lambda, I_{0}(\lambda)$ is the original intensity of radiation, before interaction with the sample, $\sigma(\lambda)$ is the absorption cross section, of the absorbing molecule at wavelength $\lambda$, and $N$ is the mean concentration of the species over the pathlength $L$ of the sample. Measurements of more than one species provide gas ratios, in an analogous manner to direct sampling; traverses or scans of volcanic clouds combined with plume

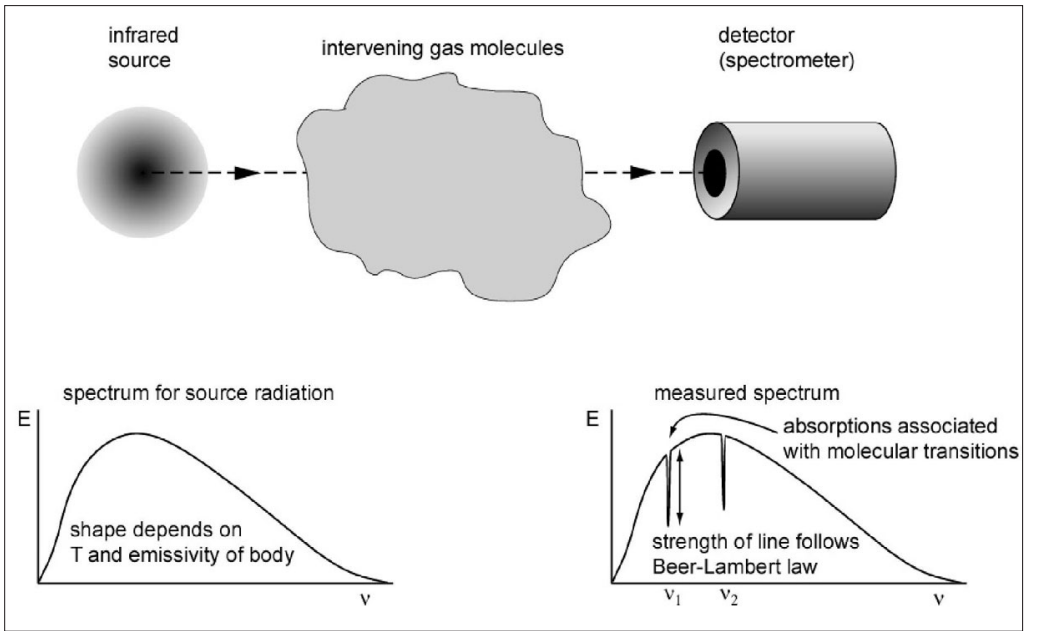

Fig. 1. Diagram of radiative transfer problem in absorption spectroscopy. From Horrocks (2001). 
transport speeds can be used to derive fluxes of gases.

The remote sensing measurements may be considered «passive» if the source of radiation is natural, and «active» if it is artificial. Examples of passive measurements include use of natural terrestrial radiation (e.g., from active lava surfaces), diffuse sky radiation, or direct solar radiation (i.e., occultation measurements). Active sources include lamps (usually used for broad spectral band observations), and lasers (sometimes multi-wavelength or «tuneable» for differential spectral measurements). The spectrometers may be dispersive, if the incoming light is separated spatially into its component wavelengths, or non-dispersive if the wavelength discrimination is achieved by other means (e.g., by interferometry). Passive measurements are invariably «open-path» observations through the free atmosphere. Active measurements may be open-path, or «closed-path» wherein the gas sample is admitted to a cell, of given path-length, through which the beam is passed. An advantage of closed-path observations is that the cell's internal pressure may be lowered to reduce pressure-broadening effects on the spectral lines, permitting high-spectralresolution measurements of trace species even in noisy regions of the spectrum. Multi-path cells of modest dimensions (e.g., $<1 \mathrm{~m})$ can simulate substantial atmospheric paths (e.g., $>100 \mathrm{~m}$ ) via multiple internal reflection.

For quantitative applications, it is usually necessary to separate out the spectral features of the volcanic gas species of interest from those of the background atmosphere (which are dominated by spectral lines originating from $\mathrm{H}_{2} \mathrm{O}$ and $\mathrm{CO}_{2}$, and molecular scattering at shorter wavelengths). This can be achieved by modelling the total atmospheric path (e.g., using a radiative transfer code, atmospheric and meteorological data, and known absorption coefficients for all relevant species), or ratio-ing spectral observations acquired for the same path with and without the volcanic plume present ( $I_{\lambda}$ and $I_{0, \lambda}$, respectively). From inspection of (2.1), it can then be seen that the column amount of a given species (i.e., the product of concentration and path length) can be obtained if $\sigma(\lambda)$ is known.

\subsection{Instrumental specifications: data acquisition}

Initial considerations in the design or exploitation of a gas sensor include the species to be targeted, and the dynamic range and sensitivity of the measurements. This requires, firstly, an appreciation of the molecules and/or isotopes worth observing from the perspective of what volcanologically-useful information they can provide, and the purpose of the investigation (volcano monitoring for activity prediction, quantification of concentrations of harmful gases, etc). The mixing of volcanic gases with the atmosphere and subsequent plume transport and dispersion act to dilute concentrations of species, making it particularly difficult to detect and measure the two principal volcanic gas components, $\mathrm{H}_{2} \mathrm{O}$ and $\mathrm{CO}_{2}$. The significant and rapid changes in humidity of the background atmosphere add to complications of sensing volcanic $\mathrm{H}_{2} \mathrm{O} . \mathrm{H}_{2} \mathrm{O}$ and $\mathrm{CO}_{2}$ also hamper spectroscopic observations of other gas species because of their abundant absorptions across the fingerprint region of the infrared spectrum, which can mask more subtle features of other trace gases.

Because of the budgetary constraints on volcano observatories and institutes, it is certainly true that it helps if instrumentation is comparatively cheap. Decisions always have to be reached in respect of costs of personnel, field vehicles and running costs, as well as equipment. However, given the potential cost benefits to society of effective volcano monitoring and accurate activity forecasts, volcanologists should be prepared to defend even expensive equipment purchases where a case can be made that the instrumentation will significantly enhance capabilities.

Observatories are often stretched not only in financial terms but also because of the many demands on the time of their personnel. This is especially the case during volcanic crises when operations are increased, and other parties (local officials, the public, the media, etc.) demand access to information. Field equipment should therefore be, generally speaking, easy to operate and maintain; data should be available in real time or near-real time, preferably with high 
time-resolution, and ideally with minimal postprocessing required. (Recording data from the COSPEC instrument - see Section 3.1.1 - has traditionally been achieved using chart recorders, demanding time-consuming, and potentially inaccurate, visual processing of the rolls of paper. This can often result in data not being processed for several days, despite their potential importance for hazards assessment). Internet-ready, digital data-streams have obvious advantages for remote access, and multi-parameter data interpretation.

Equipment should be robust enough for sustained operation, even in hostile conditions (acid gases, ash deposition, etc.), and generally low in weight in bulk, especially if its use relies on being moved around regularly and transported in vehicles (clearly, autonomous operation is the ideal since it frees up personnel for other activities). Power requirements should be modest as grid supplies are seldom an option on remote volcano locations.

\subsection{Error budgets and error reduction}

In order to interpret measurements, and the significance of any observed changes, it is crucial to understand sources and magnitudes of errors in the data. A number of data fidelity issues can be addressed in an automated fashion through various error checking regimes. Instrument response functions should be monitored regularly where necessary, with calibration and intercalibration issues addressed as appropriate. This may include careful examination of radiative transfer models, assumptions concerning atmospheric profiles, plume distribution (especially in the vertical), and Mie scattering processes.

While budgeting and reducing errors are essential exercises, they should be approached in the context of the necessary accuracy and precision for the volcanological task in hand, and the non-volcanological influences that can modify observations. For example, imagine a volcano where instantaneous $\mathrm{SO}_{2}$ gas fluxes at source may change by an order of magnitude on timescales of days. It may be sufficient to discriminate changes in flux of a factor of 5 in order to identify reliably the source signal, and therefore be unnecessary to go to great lengths to reduce errors. In respect of gas flux measurements, considerable attention has to be given to the estimation of plume transport speeds. It is widely acknowledged that uncertainty in plume speed (typically 20-40\%) represents the major contribution to errors in measurements of $\mathrm{SO}_{2}$ and other gas fluxes. A consistent approach to constraining plume speed is therefore essential. If plume speeds are poorly constrained there is little point in engineering spectrometer sensitivity to improve retrievals by only a few per cent. Absorption-correlation methods using spatially distributed instruments provide one means to track plume velocity accurately (Williams-Jones et al., 2003).

\subsection{Data interpretation}

Having secured a geochemical data-stream, the next job is to interpret it. The basic tasks are to identify volatile sources, magma-hydrother-

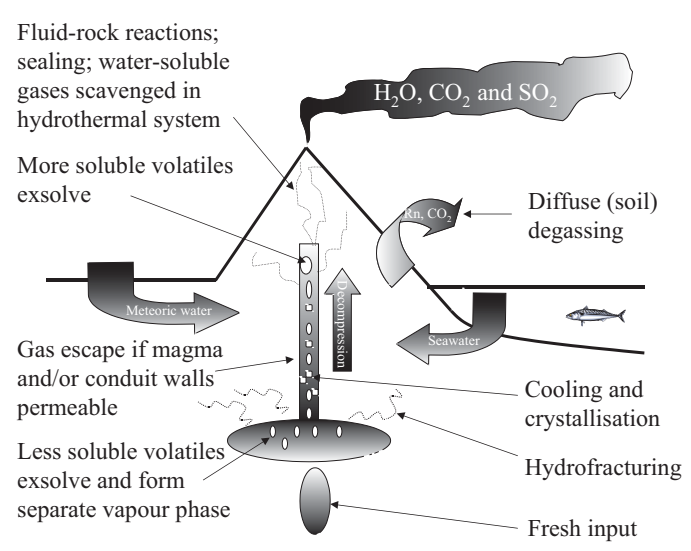

Fig. 2. Potential physical and chemical processes occurring in a magmatic-hydrothermal system, including the influence of magma dynamics in the chamberconduit plumbing system, and interactions between magmatic fluids and the crust. These can strongly modulate the speciation and flux of various magmatic components emitted into the atmosphere, complicating the interpretation of geochemical measurements of surface emissions (from Oppenheimer et al., 2003). 
mal system interactions, the dynamics of degassing, and changes in these through time. Unfortunately, interpretation of the observations is far from straightforward because of the many factors that control magmatic volatile content (mantle melting, slab contributions, wall-rock assimilation, etc.), exsolution and gas separation of different volatile species from magma, and the subsequent chemical and physical interactions of the exsolved fluids, for example, with crustal rocks and hydrothermal fluids, as they ascend to the surface (fig. 2). Although thermodynamical codes enable «restoration» of observed gas analyses to equilibrium compositions (e.g., Gerlach, 1993; Symonds et al., 1994), identifying precise magmatic and hydrothermal conditions remain real challenges. Indeed, a casual perusal of the literature will reveal conflicting interpretations of similar observations - for instance, decreasing $\mathrm{SO}_{2}$ fluxes could be due to i) depletion of volatiles in a magma body, or ii) a decrease in the permeability of the plumbing system. Process i) might indicate decreased eruption likelihood, while ii), perhaps induced by sealing of bubble networks, which would act to increase overpressure (e.g., Edmonds et al., 2003c), could increase the chance of an explosive eruption. Thus the same observation can be interpreted in different ways with contradictory hazard implications.

Advances in this area will benefit from development and validation of comprehensive physico-chemical models for volcanic degassing based on the integration of results from experiments on the controls on distribution of volatiles in synthetic and natural melts, analysis of dissolved volatiles preserved in melt inclusions, and observed volcanic gas geochemistry. Ultimately, such models can be applied to integrated geophysical, geodetic and geochemical monitoring data to support eruption forecasting.

\section{Instrumentation}

Over the last thirty years, ground-based optical remote-sensing techniques have been increasingly used for volcanic gas (and aerosol) monitoring (table I). Such techniques possess many of the advantages of seismic and deformation monitoring over direct sampling, such as the ability to obtain measurements in reasonable safety, allowing semi-continuous mon-

Table I. Overview of spectroscopic methods for ground-based optical sensing of volcanic gases.

\begin{tabular}{|c|c|c|c|}
\hline Instrument & $\begin{array}{l}\text { Transport } \\
\text { methods }\end{array}$ & $\begin{array}{l}\text { Volcanic gas species } \\
\text { detectable }\end{array}$ & $\begin{array}{l}\text { Flux measurements } \\
(\text { Yes/No) }\end{array}$ \\
\hline COSPEC & $\begin{array}{l}\text { car, aircraft, } \\
\text { boat }\end{array}$ & $\mathrm{SO}_{2}$ & Yes \\
\hline $\begin{array}{l}\text { UV grating spectrometers } \\
\text { (e.g., Ocean Optics USB 2000) }\end{array}$ & $\begin{array}{l}\text { on foot, car, } \\
\text { aircraft, boat }\end{array}$ & $\mathrm{SO}_{2}, \mathrm{H}_{2} \mathrm{~S}, \mathrm{BrO}$ & Yes \\
\hline $\begin{array}{l}\text { FTIR (e.g., Brucker OPAG 22, } \\
\text { MIDAC AM series) }\end{array}$ & car & $\begin{array}{l}\mathrm{CO}_{2}, \mathrm{CO}, \mathrm{OCS}, \mathrm{CH}_{4} \\
\mathrm{SO}_{2}, \mathrm{H}_{2} \mathrm{O}, \mathrm{HCl}, \mathrm{HF}, \mathrm{SiF}_{4}\end{array}$ & Yes (with sun-tracker) \\
\hline $\begin{array}{l}\text { Other NDIR (e.g., LI-COR } \mathrm{CO}_{2} \\
\text { analysers) }\end{array}$ & on foot, aircraft & $\mathrm{CO}_{2}, \mathrm{H}_{2} \mathrm{O}$ & $\begin{array}{l}\text { Yes (by plume profiling } \\
\text { or ground flux surveys) }\end{array}$ \\
\hline $\begin{array}{l}\text { DIAL (i.e., using atmospheric } \\
\text { backscatter to return signal) }\end{array}$ & truck, ship & $\begin{array}{l}\mathrm{SO}_{2} \text {, other species feasi- } \\
\text { ble }\end{array}$ & Yes \\
\hline $\begin{array}{l}\text { Laser spectroscopy (short path, } \\
\text { extractive) }\end{array}$ & car & as FTIR plus isotopes & No \\
\hline
\end{tabular}


itoring even through violent eruptive periods. Additionally, gas concentrations may be retrieved non-invasively in near real-time, obviating the need for subsequent laboratory analysis, and eliminating the possibility of sample contamination. Because remote sensing techniques measure integrated gas concentrations through cross sections of the plume, in contrast to in situ sampling, they can potentially yield a more representative picture of bulk plume composition and flux.

In the following subsections, we briefly review some recent developments in optical sensing applications to volcanic gas surveillance. With the exception perhaps of the ASTER sensor on NASA'S Terra platform, spaceborne remote sensing is unlikely, in the near future, to provide a capability for frequent measurements of weaker tropospheric volcanic plumes, e.g., sustained by quiescent degassing. We focus, therefore, on ground-based approaches that are suitable for routine monitoring applications. For a fuller review of the field, including spectroscopic determination of volcanic aerosol concentrations and properties, see McGonigle and Oppenheimer (2003).

\subsection{UV spectroscopy}

\subsubsection{Correlation mask instruments: COSPEC}

Arguably, the most widely applied instrument for ground-based remote-sensing of volcanic plumes is the Barringer Research COSPEC, which was originally developed to measure industrial $\mathrm{SO}_{2}$ and $\mathrm{NO}_{\mathrm{x}}$ emissions (Moffat and Millán, 1971). Over the last thirty years, openpath ultraviolet (OPUV) COSPEC $\mathrm{SO}_{2}$ measurements have been performed at numerous volcanoes worldwide (e.g., Casadevall et al., 1984; Stoiber et al., 1986; Caltabiano et al., 1994; Gerlach et al., 1998, and references therein). The COSPEC is typically operated by measuring the absorption of ultraviolet (UV) zenith skylight, by overhead $\mathrm{SO}_{2}$ (Millán and Hoff, 1978). This is achieved by dispersing the collected skylight with a grating and then imaging this spectrum on to the radial length of a spinning disk, behind which is a detector. The disk has segments with etchings at radii that block light «correlating» either to wavelengths of low or high absorption (in the spectral region 300-315 nm), such that the output signal from the detector is modulated according the absorption of overhead $\mathrm{SO}_{2}$. (A development of this form of correlation spectroscopy is to mount cells containing the gases of interest on a rotating chopper disk, in an analogous fashion to the COSPEC's etched masks. This gas correlation filter spectrometry method has been implemented to sense volcanic $\mathrm{CO}$ and OCS concentrations but operating in the infrared spectral region (Stix et al., 1996).

Internal electronic processing yields $\mathrm{SO}_{2}$ concentrations (in parts per million meters ppm m; see Gerlach, 2003, for discussion of the problems inherent in use of these units), and calibration is achieved by placing quartz cells containing known amounts of $\mathrm{SO}_{2}$ in the internal optical path of the spectrometer. Fluxes are obtained by traversing underneath the plume, approximately perpendicular to its axis, in a road vehicle, boat or aircraft, and recording $\mathrm{SO}_{2}$ concentration as a function of position (from a GPS receiver). By integrating the concentrations across the plume and multiplying by plume speed, $\mathrm{SO}_{2}$ fluxes are derived (typically expressed in tonnes per day, $\mathrm{t} \mathrm{d}^{-1}$, or $\mathrm{kg} \mathrm{s}^{-1}$ ).

The COSPEC possesses many advantages as a tool for volcanic surveillance. As this device operates using scattered skylight, alignment is trivial and measurements are possible in overcast conditions. However the accuracy of the derived fluxes is very dependent on the adequacy of the plume speed data (Stoiber et al., 1983). Typically, the wind speed is obtained from distant radiosonde data, visual observations of the moving plume, or ground based anemometry. More accurate wind data can be obtained by videography, or from aircraft navigational equipment in the case of airborne traverses. A further source of error is that the diffuse skylight can be scattered into the COSPEC's field of view from above, below or within the plume (Millán, 1980; Moffat and Millán, 1971), in contrast to the flux calculation's assumption that light passes vertically through the entire plume. Scattering effects in ash-laden 
plumes can introduce further scattering related errors (Andres and Schmid, 2001).

The COSPEC was originally applied in a volcanological context to assess whether changes in $\mathrm{SO}_{2}$ gas fluxes could be associated with changes in eruptive activity of open conduit volcanoes (i.e. rising or falling of magmas, and sealing or opening of magma chambers). Positive correlations of increasing $\mathrm{SO}_{2}$ flux with activity were observed during measurements at Mt. Etna (Malinconico et al., 1979). In 1991, the $\mathrm{SO}_{2}$ flux of Mt. Pinatubo was observed to increase by an order of magnitude over two weeks, in parallel with seismic unrest, providing evidence for a shallow intrusion of magma, and prompting a civil evacuation (Hoff, 1992; Daag et al., 1996). Decreasing COSPEC $\mathrm{SO}_{2}$ fluxes in parallel with decreasing post-eruptive activity have also been observed on many volcanoes, notably at Mt. St. Helens from 1980 to 1988 (McGee, 1992), following the 1980 eruption. Through COSPEC a catalogue of fluxes from actively and passively degassing volcanoes worldwide has been obtained, from which the total volcanic $\mathrm{SO}_{2}$ flux to the atmosphere has been estimated at $\sim 20 \mathrm{Tg} \mathrm{yr}^{-1}$ (Stoiber and Jepsen, 1973; Berresheim and Jaeschke, 1983; Stoiber et al., 1987; Andres and Kasgnoc, 1998). COSPEC measurements have also revealed that many volcanoes emit $\mathrm{SO}_{2}$ in excess of levels that could be sustained by degassing of their erupted magmas, highlighting the socalled «excess sulfur» issue (Wallace, 2001).

However, interpreting COSPEC data can be complicated. For instance, in the past both increasing and decreasing flux signatures have been found to pre-empt changes in volcanic activity (Symonds et al., 2001). Furthermore, $\mathrm{SO}_{2}$ fluxes are modulated by the action of hydrothermal systems (Doukas and Gerlach, 1995; Oppenheimer, 1996; Symonds et al., 2001) and during transport in the atmosphere through deposition and chemical transformations (Malinconico, 1979; Oppenheimer et al., 1998a). This is partly why monitoring gas ratios can be so informative. A final, more practical problem is that the COSPEC is no longer in routine production, and servicing and sourcing replacement parts is becoming increasingly costly and difficult.

\subsubsection{Broad band measurement and spectral analysis}

A potential drawback of the COSPEC is its «black box» nature. The original design of the COSPEC was very much engineering-oriented, with the goal to build a system capable of minimizing all «noise» (i.e., other atmospheric absorptions, etc.) to deliver information on just one species (e.g., $\mathrm{SO}_{2}$ ). The result is an instrument that yields an estimate of the column amount of $\mathrm{SO}_{2}$ in the field of view. While this greatly simplifies data retrieval and processing, it makes it difficult to assess potential errors that arise from wavelength shifts, scattering and solar elevation effects, thermal and mechanical distortions, etc. Also, the COSPEC response depends on the mask used and the concentration of gases present. An alternative approach is to measure broad band spectra with sufficient spectral resolution to be able to model trace gas concentrations. This ap-

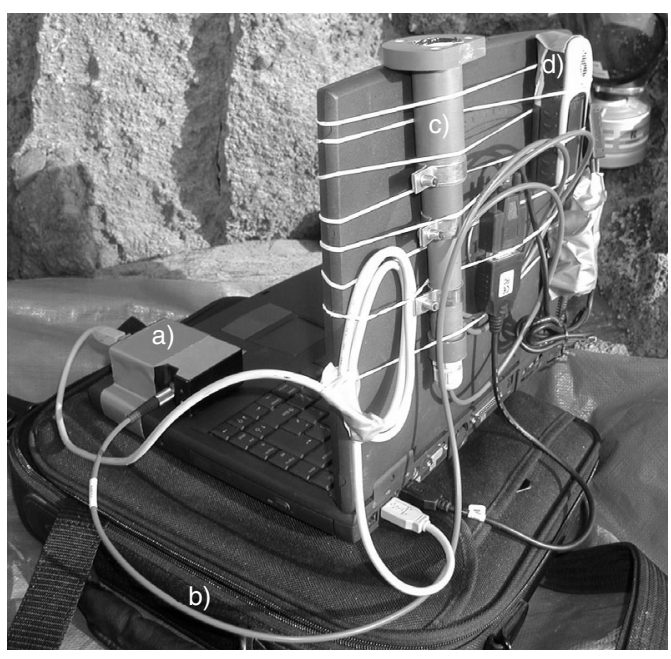

Fig. 3. Simple configuration of instrumentation for OPUV measurements using mimniature spectrometer (a) connected by fibre optic cable (b) to telescope (c). GPS receiver (d) provides continuous tracking to locate all spectra saved to laptop computer via USB cable. The ensemble could be further reduced in size and weight by replacing the laptop computer with a palm top unit. A reflective screen is desirable for visibility and enhanced battery life. 


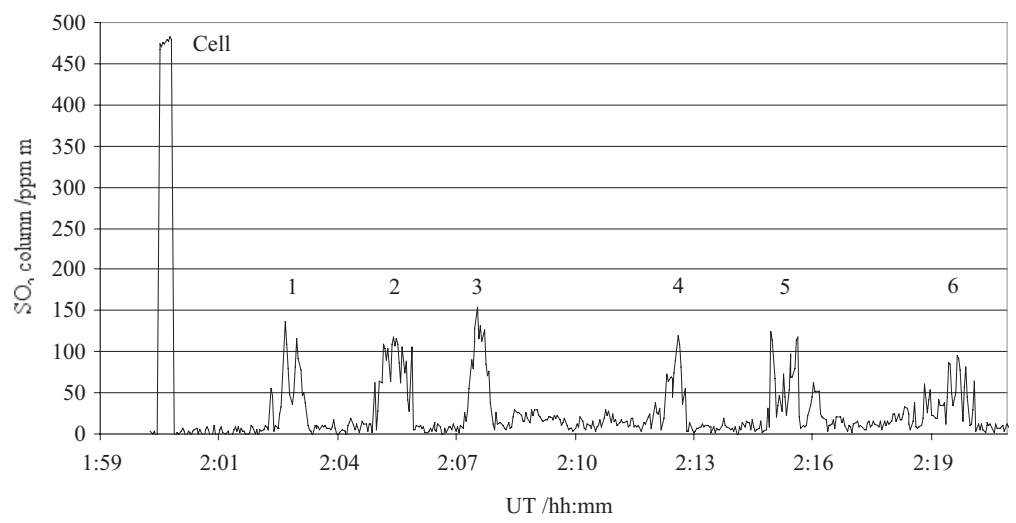

Fig. 4. Example of raw data collected in real-time by walking traverse at Meakan-dake volcano, Japan, using equipment shown in fig. 3. The first excursion shows a $\mathrm{SO}_{2}$-filled quartz cell placed in front of the telescope. Six backand-forth traverses beneath the plume, a few tens of metres from the source, follow. The timescale is subsequently corrected using the GPS log to a distance scale perpendicular to the plume transport direction. This provides the column cross section of $\mathrm{SO}_{2}$, which is then multiplied by plume speed to yield flux. In this case the $\mathrm{SO}_{2}$ emission amounts to around $40 \mathrm{~g} \mathrm{~s}^{-1}$, highlighting the capability to measure very low fluxes from individual fumaroles.

proach is often termed differential optical absorption spectroscopy (DOAS; Platt, 1994).

The first volcanological DOAS observations were performed at sea from 1992 to 1997 (Edner et al., 1994; Weibring et al., 1998), to measure the $\mathrm{SO}_{2}$ emitted by Etna, Stromboli and Vulcano. In general, the scattered skylight is collected using a vertically pointing telescope, and coupled into the spectrometer with an optical fibre, i.e., the same OPUV approach used for COSPEC. Direct solar UV (i.e., Sun occultation) is also used in DOAS observations, which has the advantage of simplifying the radiative transfer problem. Light is generally spectrally dispersed using a grating, and spectra are collected using a CCD array (or photomultiplier tube and scanning mechanism) outside the plume, through the plume, and with light blocked from entering the spectrometer (to read the «dark current»). In the retrieval process the latter spectra are subtracted from the former two types in order to reduce instrumental noise effects. All the «plume spectra» are then divided by an out-of-plume «background» spectrum, in order to reduce interferences caused by background atmospheric absorption and the solar spectral structure (Fraunhofer lines). The logarithm of the result is taken (along with high- and low-pass filter stages), following Beer's law (2.1), and then $\mathrm{SO}_{2}$ concentrations are derived by scaling a reference spectrum of known column amount over the $\sim 303-315 \mathrm{~nm}$ fitting region to match the observed spectrum.

The instrument used on the Italian volcanoes was comparatively bulky. More recently, in 2001, volcanological field tests were carried out with a commercially available, miniature ultraviolet spectrometer (fig. 3; Galle et al., 2003). This instrument is considerably smaller, lighter, cheaper, and lower in power consumption, than the COSPEC (Galle et al., 2003) but the performance is comparable. Side-by-side intercomparisons with a COSPEC at Soufrière Hills Volcano (Montserrat) and Mt. Etna revealed good correspondence between the two instruments (Galle et al., 2003; McGonigle et al., 2003). Given the favourable characteristics of the smaller device, it is already attracting interest in the volcanological research community as a replacement technology for COSPEC. Because of its genuine portability (rather than «transportability», which better describes many other devices sold on the market with claims to be «portable»), $\mathrm{SO}_{2}$ flux measurements can even be obtained by traversing beneath the plume on foot (fig. 4). This opens up the possibility of measurements at vol- 
canoes that lack suitable roads or other forms of vehicular access, with a minimum of logistical support, and avoiding the high costs of airborne operation (McGonigle et al., 2002).

The miniature UV spectrometer can be readily adapted for scanning measurements, whereby the field of view is manually turned through the plume (e.g., from horizon to horizon; McGonigle et al., 2002. It has also been configured for automated fixed position flux measurements, by way of a $45^{\circ}$ turning mirror rotated by a stepper motor (Galle et al., 2002; McGonigle et al., 2003; Edmonds et al., 2003a). A particularly promising development is the installation of a number of automated and telemetered plume scanners by the Montserrat Volcano Observatory (MVO) for Soufrière Hills Volcano. The use of multiple instruments in different locations helps in observing the plume under varying wind directions, and to permit crude, tomography-style retrieval of range-resolved $\mathrm{SO}_{2}$ concentrations. This system is now delivering high temporal resolution (every few minutes) sustained $\mathrm{SO}_{2}$ flux data during daylight hours (Edmonds et al., 2003a). Such data will provide unprecedented opportunities for the cross-correlation of timestamped geodetic, seismic and geochemical data streams, promising new volcanological insights into degassing and magma dynamics.

By virtue of recording spectra, broadband UV spectroscopy has the capability of detecting multiple gas species. Measurements of $\mathrm{H}_{2} \mathrm{~S} / \mathrm{SO}_{2}$ ratios have recently been accomplished at Vulcano, Italy using the miniature UV spectrometer in a closed-path configuration (i.e., with a fixed path-length cell and artificial UV source; O'Dwyer et al., 2003). The same instrument, applied to sky OPUV measurements at Montserrat, yielded $\mathrm{SO}_{2} / \mathrm{BrO}$ ratios in the volcanic plume (the $\mathrm{BrO}$ being the oxidation product of volcanic HBr; Bobrowski et al., 2003).

\subsection{Non-dispersive infrared (NDIR) spectroscopy}

As discussed, it is desirable, in many cases, to measure not only $\mathrm{SO}_{2}$ but other volcanic gas species. This has been one of the great benefits of the conventional direct sampling approach to gas geochemistry, since many species can be measured down to ppt levels using laboratory analytical techniques. Of particular relevance, the availability over the last ten years or so of field portable, robust Fourier transform infrared (FTIR) spectrometers has extended the capabilities of remote sensing of volcanic gases in this direction. These devices operate across the socalled fundamental region of the infrared spectrum, providing access to the rotation-vibration absorption features of, among other species, $\mathrm{HCl}, \mathrm{H}_{2} \mathrm{O}, \mathrm{SO}_{2}, \mathrm{HF}, \mathrm{CO}_{2}, \mathrm{SiF}_{4}, \mathrm{OCS}$ and $\mathrm{CO}$.

FTIR spectrometers are based on Michelson interferometers, in which incoming light is split into two beams using an optical beam-splitter, which also recombines these beams after they are reflected at mirrors. One of the mirrors in scanned back and forth along the axis of its beam, introducing a variable path difference between the two beams, resulting in a time-variable signal from the single broad-band detector due to interference of recombined beams. Application of an inverse Fourier transform to the temporal signal yields spectra, which are analysed (using radiative transfer models or by ratio-ing in-plume and out-of-plume spectra) in order to determine the concentrations of volcanic gases absorbing in the optical path. A range of IR light sources: direct sunlight, fire fountains, artificial IR lamps, and hot rocks have been used in volcano FTIR surveillance highlighting the flexibility of the approach to adapt to the circumstances of activity, access and terrain. Love et al. $(1998,2000)$ have shown it is also possible to measure volcanic gases in emission (i.e., their emission lines rather than their absorption lines) against a cold sky background. At Popocatépetl volcano, Mexico, Love et al. (1998) observed a steady increase in $\mathrm{SiF}_{4} / \mathrm{SO}_{2}$ ratio prior to an eruption in February 1997, followed by a tenfold decrease within a few hours. These results suggested a cooling of the gas prior to the eruption, attributed to adiabatic gas expansion on release of a conduit plug.

The first FTIR volcanic gas spectroscopy was carried out in 1991 at Asama volcano, Japan, (Notsu et al., 1993), by Japanese researchers who have subsequently reported measurements at Unzen, Japan $\left(\mathrm{SO}_{2}\right.$ and $\mathrm{HCl}$; Mori et al., 1993), Aso, Japan (CO, OCS, $\mathrm{CO}_{2}, \mathrm{SO}_{2}$ and 
$\mathrm{HCl}$; Mori and Notsu 1997), and Vulcano, Italy $\left(\mathrm{SO}_{2}\right.$ and $\mathrm{HCl}$; Mori et al., 1995). The $\mathrm{CO} / \mathrm{CO}_{2}$ ratio obtained at Aso was used to constrain fumarole temperatures. Further developments have been undertaken by a UK-based group (Francis et al., 1995; Francis et al., 1996; Oppenheimer et al., 1998c, 2002; Francis et al., 2000). The last of these works permitted plume temperature estimates based on $\mathrm{HF} / \mathrm{SiF}_{4}$ ratio obtained at Vulcano. Later work on Mt. Etna resulted in the first FTIR spectroscopy of volcanic plumes by solar occultation (Francis et al., 1998).

Since 1998, this group has carried out annual campaigns at Masaya volcano, Nicaragua, where high volcanic gas concentrations permitted measurements of volcanic $\mathrm{CO}_{2}$ and $\mathrm{H}_{2} \mathrm{O}$, in spite of these species' high ambient concentrations (Burton et al., 2000). Measurements at Masaya indicated consistent $\mathrm{SO}_{2} / \mathrm{HCl}$ and $\mathrm{HCl} / \mathrm{HF}$ molar ratios of 1.6 and 5, respectively, during 1998-2000, indicating steady-state, open system degassing (Horrocks et al., 1999). In contrast, in 2001 a $\mathrm{SO}_{2} / \mathrm{HCl}$ ratio of 4.5 was found, coinciding with reduced $\mathrm{SO}_{2}$ fluxes, descent of the magma column in the vent on the crater floor, and preceding a small explosive eruption on the 23rd April (Duffell et al., 2003). Traverse flux measurements of $\mathrm{HCl}$ have also been obtained by operating the FTIR spectrometer with a solar tracker, in contrast to the usual method of combining OPUV-derived $\mathrm{SO}_{2}$ fluxes with $\mathrm{SO}_{2} / \mathrm{HCl}$ ratios from FTIR spectroscopy or direct sampling (Duffell et al., 2001).

FTIR measurements at Soufrière Hills Volcano, Montserrat have indicated that $\mathrm{HCl} / \mathrm{SO}_{2}$ molar ratios of 1-5 typify dome building episodes, and that lower ratios (down to 0.1 ) characterise non-eruptive periods (Oppenheimer et al., 1998d, 2002; Edmonds et al. 2001, 2002, 2003b). This behaviour has been explained in terms of an andesitic $\mathrm{HCl}$ source that exsolves on ascent from the magma chamber, and a deeper $\mathrm{SO}_{2}$ reservoir (probably derived from intruded mafic magma) that degasses to the atmosphere discontinuously, depending on the plumbing system's permeability. Based on this interpretation, Edmonds et al. (2002) have identified the potential degassing signals that might herald the end of this eruption. Oppenheimer et al. (1998b) demonstrated the ap- plication of FTIR spectroscopy from a helicopter at distances of $\approx 100 \mathrm{~m}$ from the lava dome.

The first routine FTIR spectroscopic volcano surveillance programme has been running since April 2000, at Mt. Etna, under the auspices of the Istituto Internazionale per Geofisica e Vulcanolgia (INGV; Burton et al., 2003). The results obtained to date serve as an excellent advertisement for the value of FTIR spectroscopy in complementing other surveillance efforts (e.g., geodesy, seismology and petrology), and in supporting monitoring efforts during volcanic crises (Calvari, 2001). In particular, a doubling of the $\mathrm{SO}_{2} / \mathrm{HCl}$ ratio was observed prior to the $2001 \mathrm{Mt}$. Etna eruption and clear geochemical trends in $\mathrm{SO}_{2} / \mathrm{HCl}, \mathrm{CO}_{2} / \mathrm{SO}_{2}$, and $\mathrm{HCl} / \mathrm{HF}$ for different active vents at different elevations through the course of the eruption. These kinds of data would have been impossible to collect in real time by any conventional technique. While the operation of FTIR spectrometers is relatively straightforward, processing the spectra and retrieving gas column amounts requires some expertise.

Representing another class of NDIR spectrometer in volcanological use are the instruments manufactured by LI-COR. These are generally dual-wavelength closed-path analysers, and have been used to measure both diffuse $\mathrm{CO}_{2}$ emissions from the ground (McGee et al., 2000), and $\mathrm{CO}_{2}$ fluxes by in-plume sampling (Gerlach et al., 1998). A third application of LI-COR is based on eddy correlation or covariance, which involves measurements of vertical windspeed and $\mathrm{CO}_{2}$ concentration (e.g., Anderson and Farrar, 2001).

\subsection{Laser techniques}

To date, the most commonly applied laser technique for volcano measurements is lidar, in which a pulsed laser beam is directed towards the plume. Recording the temporally varying intensity of backscattered light provides information about the atmospheric composition as a function of propagation distance along the beam's path. lidar has been used to measure concentrations and fluxes (via traverses) of sulfate aerosol (Casadevall et al., 1984; Edner 
et al., 1994; Porter et al., 2002), and ash (Hobbs et al., 1991). Parallel gas sampling and aerosol measurements can enable estimation of gas to particle conversion rates (e.g., for $\mathrm{SO}_{2}$ to $\mathrm{SO}_{4}{ }^{2-}$ Stith et al., 1978; Radke, 1982; Rose et al., 1986). Although studies of anthropogenic plumes indicate $\mathrm{SO}_{2}$ to $\mathrm{SO}_{4}{ }^{2-}$ conversion rates of a few $\% h^{-1}$ in the lower troposphere (Eatough et al., 1994), very few comparable investigations of volcanic plumes (which can have widely varied gas, ash and liquid water contents) have been undertaken (e.g., Oppenheimer et al., 1998a; Rose et al., 2001; Horrocks et al., 2003).

A variation on lidar, known as differential absorption lidar (DIAL) involves rapid switching the frequency of laser pulses on- and off-resonance of an absorption feature of the gas of interest. By dividing the lidar curves (returned signal versus height) obtained at the two wavelengths and applying the Beer-Lambert law, range-resolved gas concentrations (ppm) may be derived providing $2 \mathrm{D}$ or $3 \mathrm{D}$ plume structure, in contrast to the pathlength integrated concentrations (ppm m) obtained from FTIR, COSPEC and DOAS. The technique has been applied to the Southern Italian volcanoes using UV lasers (Edner et al., 1994), in parallel with COSPEC and UVDOAS instruments, revealing $\mathrm{SO}_{2}$ concentrations up to $50 \%$ higher in the former case as a consequence of scattering-induced errors in the passive techniques. However, this DIAL apparatus was costly, heavy and bulky. Whilst DIAL offers unique capabilities for volcanology, it requires further innovation in order to become a suitable tool for routine observatory use.

Alternative sensing strategies using near and mid-infrared diode based lasers (Gianfrani et al., 2000; De Natale et al., 2001; Richter et al., 2002) have been evaluated by monitoring the laser's absorption following numerous transits of a multipass cell, into which the volcanic gas sample is pumped. Due to the very narrow linewidths lasers can provide, the most promising application of these techniques is in spectrally resolving between isotopes to provide infield isotope ratios. Whilst only gas ratio measurements have been realised to date in the field, Richter et al. (2002) and Weidmann et al. (2003) have described a mid-IR laser system capable of measuring all isotopes of $\mathrm{CO}_{2}$, while Gianfrani et al. (2003) have presented a diode laser spectrometer able to measure water isotopes in the near-IR. An additional laser based technique that shows potential for field isotope measurements is photoacoustic spectroscopy, in which the sound waves, generated by resonant laser light exciting the target species, are measured (Meyer and Sigrist, 1990).

\section{Concluding remarks}

Surveillance of gas composition and flux are essential for interpretation of volcanic activity, since the nature of degassing exerts a strong control on eruption style, and is closely associated with volcano seismicity and ground deformation. New optical remote sensing techniques are emerging for the monitoring of volcanic emissions such as the miniature ultraviolet spectrometers described by Galle et al. (2003). These tools and their data-streams have the potential for full automation and telemetry, fast processing and evaluation, closer integration with other monitoring data-streams (i.e., seismic, geodetic, etc.), and more sophisticated modelling and interpretation.

While instrument developments are always to be encouraged, we believe that the state of the art is already adequate to justify the proliferation of both IR and UV spectroscopic tools amongst the volcano observing community. This is beginning to happen, with FTIR spectroscopy routinely applied to monitoring of the Southern Italian volcanoes by INGV, and UV methods used on Montserrat by MVO. In addition to the immediate monitoring and hazard evaluation goals of such institutes, sustained surveillance programmes promise the most significant science gains in the future, as geochemical, geodetic and seismic datastreams are further integrated, cross-correlated, and modelled.

As we introduce tools that will replace or supplement other methods, it is crucial that we maintain continuity between old and new datasets. This demands the direct comparison and intercalibration of the various gas geochemical tools via laboratory and field experimentation, 
as carried out periodically by the IAVCEI Commission on Volcanic Gases. Additionally, it helps to conform to internationally recognized data standards. One attractive development in this respect is the «WOVOdat» concept of the World Organisation of Volcano Observatories, which aims to establish standardised units and formats for surveillance data so that they may be brought together in a unified, digital database, accessible via the Web and linked with the Smithsonian Institution's unique database of historical eruptions. A further important benefit of proliferating optical sensing techniques capable of gas flux measurements is that this will lead to more accurate, and time-resolved estimates of the global emission of volcanic volatiles to the atmosphere.

\section{Acknowledgements}

We gratefully acknowledge research support from the Gruppo Nazionale per la Vulcanologia (project «Development of an integrated spectroscopic system for remote and continuous monitoring of volcanic gas»), the European Commission 5th Framework programme (projects «MULTIMO; http://earth.leeds.ac.uk/ aj/Multimo/» and «DORSIVA»), and the UK Natural Environment Research Council project «Field laser spectroscopy of volcanic gases and their isotopes» and Research Fellowship awarded to AJSM. This work originates from the tremendous Workshop-Short Course on Volcanic Systems held in Seiano (Napoli) in September 2002 «Geochemical and Geophysical Monitoring: melt inclusions: methods, applications and problems» organized by B. De Vivo, R.J. Bodnar, E. Boschi and G. Macedonio. We thank especially our colleagues in Italy with whom we have worked over the past years: Mike Burton, Tommaso Caltabiano, Sonia Calvari, Giovanni Chiodini, Salvatore Inguaggiato, Filippo Murè, Paolo De Natale, Pino De Natale, Alessandra Rocco and Giuseppe Salerno.

\section{REFERENCES}

ANDERSON, D.E. and C.D. FARRAR (2001): Eddy covariance measurement of $\mathrm{CO}_{2}$ flux to the atmosphere from an area of high volcanogenic emissions, Mammoth Mountain, California, Chem. Geol., 177, 31-42.

ANDRES, R.J. and A.D. KASGNOC (1998): A time-averaged inventory of subaerial volcanic sulfur emissions, $J$. Geophys. Res., 103, 25251-25261.

ANDRES, R.J. and J.W. SCHMID (2001): The effects of volcanic ash on COSPEC measurements, J. Volcanol. Geotherm. Res., 108, 237-244.

BAXTer, P.J., R.E. Stoiber and S.N. Williams (1982): Volcanic gases and health: Masaya Volcano, Nicaragua, Lancet, 2, 150-151

BerResheiM, H. and W. JAESCHKE (1983): The contribution of volcanoes to the global atmospheric sulphur budget, J. Geophys. Res., 88, 3732-3740.

Bobrowski, N., G. Hönninger, B. Galle and U. Platt (2003): Detection of bromine monoxide in a volcanic plume, Nature, 423, 273-276.

Burton, M.R., C. OpPenheimer, L.A. Horrocks and P.W. FRANCIS (2000): Remote sensing of $\mathrm{CO}_{2}$ and $\mathrm{H}_{2} \mathrm{O}$ emission rates from Masaya Volcano, Nicaragua, Geology, 28, 915-918.

Burton, M., P. Allard, F. Murè and C. Oppenheimer, (2003): FTIR remote sensing of fractional magma degassing at Mt. Etna, Sicily, in Volcanic degassing, edited by C. Oppenheimer, D.M. Pyle and J. BARClay, Geol. Soc., London, Spec. Publ. 213, 281-293.

Caltabiano, T., R. Romano and G. Budetta (1994): $\mathrm{SO}_{2}$ flux measurements at Mt. Etna, J. Geophys. Res., 99, 12809-12819.

CAlvari, S. (2001): Multidisciplinary approach yields insight into Mt. Etna eruption, Eos Trans. Am. Geophys. Un., 82, 653, 656.

Casadevall, T.J., W.I. Rose, W.H. Fuller, W.H. Hunt, M.A. Hart, J.L. Moyers, D.C. Woods, R.L. Chuan and J.P. FRIEND (1984): Sulfur dioxide and particles in quiescent volcanic plumes from Poas, Arenal, and Colima volcanoes, Costa Rica and Mexico, J. Geophys. Res., 89, 9633-9641.

ChIN, M. and D.J. JACOB (1996): Anthropogenic and natural contributions to tropospheric sulfate: a global model analysis, J. Geophys. Res., 101, 18691-18699.

DaAg, A.S., B.S. Tubianosa, C.G. Newhall, N.M. TuÑGol, D. JaVier, M.T. Dolan, P.J. Delos Reyes, R.A. Arboleda, M.L. Martinez and T.M. Regalado (1996): Monitoring sulfur dioxide emission at Mount Pinatubo, in Fire and Mud: Eruptions and Lahars of Mount Pinatubo Philippines, edited by C.G. NEwHALL, R.S. PunOngbayan (Philippine Institute of Volcanology and Seismology, Quezon City and University of Washington Press, Seattle), 409-434.

De Natale, P., L. Gianfrani and G. De Natale (2001): Optical methods for monitoring volcanoes: techniques and new perspectives, J. Volcanol. Geotherm. Res., 109, 235-245.

Delmelle, P., Monitoring and environmental impacts of tropospheric volcanic gas plumes, in Volcanic degassing, edited by C. OPPENHEIMER, D.M. PYLE and J. Barclay, Geol. Soc., London, Spec. Publ. 213, 381399.

DoukAS, M.P. and T.M. GERLACH (1995): Sulfur dioxide scrubbing during the 1992 eruptions of Crater Peak, Mount Spurr Volcano, Alaska, in The 1992 eruptions of Crater Peak vent, Mount Spurr volcano, Alaska, edited by T.E.C. KeITH, U.S. Geol. Surv. Bull., 2139, 47-57. 
Duffell, H., C. OpPenheimer and M.R. Burton (2001): Volcanic gas emission rates measured by solar occultation spectroscopy, Geophys. Res. Lett., 28, 3131-3134.

Duffell, H.J., C. Oppenheimer, D. Pyle, B. Galle, A.J.S. McGonigle and M.R. BurTon (2003): Geochemical precursors to a minor explosive eruption at Masaya volcano, Nicaragua, J. Volcanol. Geotherm. Res., 126, 327-339.

Eatough, D.J., F.M. CAKA and R.J. FARber (1994): The conversion of $\mathrm{SO}_{2}$ to sulfate in the atmosphere, Isr. J. Chem., 34, 301-314.

Edmonds, M., D. Pyle and C. OpPenheimer (2001): A model for degassing at the Soufrière Hills Volcano, Montserrat, West Indies, based on geochemical data, Earth Plan. Sci. Lett., 186, 159-173.

Edmonds, M., D. Pyle and C. OPPEnheIMER (2002): $\mathrm{HCl}$ emissions at Soufrière Hills Volcano, Montserrat, West Indies, during the second phase of dome-building: November 1999 to October 2000, Bull. Volcanol., 64, 21-30.

Edmonds, M., R.A. Herd, B. Galle and C. OpPenheimer (2003a): Automated, high time-resolution measurements of $\mathrm{SO}_{2}$ flux at Soufrière Hills Volcano, Montserrat, Bull. Volcanol. 65, 578-586.

Edmonds, M., C. Oppenheimer, D. Pyle and R. Herd (2003b): Rainwater and ash leachate analysis used to monitor plume chemistry at Soufrière Hills Volcano, Montserrat, West Indies, in Volcanic Degassing, edited by C. Oppenheimer, D.M. Pyle and J. Barclay, Geol. Soc. London, Spec. Publ. 213, 203-218.

Edmonds, M., C. OPPEnHEIMER, D.M. Pyle, R.A. Herd and G. THOMPSON $(2003 \mathrm{c})$ : $\mathrm{SO}_{2}$ emissions from Soufrière Hills Volcano and their relationship to conduit permeability, hydrothermal interaction and degassing regime, J. Volcanol. Geotherm. Res., 124, 23-43.

Edner, H., S. Ragnarson, S. Svanberg, E. Wallinder, R. FERrERA, R. CiONI, B. RACO and G. TADDEUCCI (1994): Total fluxes of sulfur dioxide from the Italian Volcanoes Etna, Stromboli and Vulcano measured by differential absorption lidar and passive differential optical absorption spectroscopy, J. Geophys. Res., 99, 1882718838.

Francis, P., A. Maciejewsi, C. Oppenheimer, C. Chaffin, and T. Caltabiano (1995): $\mathrm{SO}_{2}: \mathrm{HCl}$ ratios in the plumes from Mt. Etna and Vulcano determined by Fourier transform spectroscopy, Geophys. Res. Lett., 22, 1717-1720.

Francis, P., C. Chaffin, A. Maciejewsisi and C. OpPenHEIMER (1996): Remote determination of $\mathrm{SiF}_{4}$ in volcanic plumes: a new tool for volcano monitoring, Geophys. Res. Lett., 23, 249-252.

Francis, P., M. Burton and C. OpPenheIMER (1998): Remote measurements of volcanic gas compositions by solar FTIR spectroscopy, Nature, 396, 567-570.

Francis, P., L. Horrocks and C. OPPENHEIMER (2000): Monitoring gases from andesite volcanoes, Philos. Trans. R. Soc., 358, 1567-1584.

Fujita, S., T. SAKurai and K. Matsuda (2003): Wet and dry deposition of sulfur associated with the eruption of Miyakejima volcano, Japan, J. Geophys. Res., 108 (D15), 4444, doi:10.1029/2002JD003064.

Galle B., M. Edmonds, A. Geyer and R. Herd (2002): A novel spectroscopic system for continuous measure- ments of volcanic $\mathrm{SO}_{2}$ emissions with high time resolution, Montagne Pelée 1902-2002, in Explosive Volcanism in Subduction Zones, IAVCEI Conference, 1216 May, Saint Pierre, Martinique.

Galle, B., C. Oppenheimer, A. Geyer, A. McGonigle, M. EDMONDS and L.A. Horrocks (2003): A miniaturised ultraviolet spectrometer for remote sensing of $\mathrm{SO}_{2}$ fluxes: a new tool for volcano surveillance, J. Volcanol. Geotherm. Res., 119, 241-254.

GerLaCH, T.M. (1993): Thermodynamic evaluation and restoration of volcanic gas analyses; an example based on modern collection and analytical methods, Geochem. J., 27, 305-322.

GERLACH, T.M. (2003): Elevation effetcs in volcano applications of the COSPEC, in Volcanic degassing, edited by C. Oppenheimer, D.M. Pyle and J. Barclay, Geol. Soc. London, Spec. Publ. 213, 169-175.

Gerlach, T.M. and T.M. Casadevall (1986): Fumarole emission at Mount St Helens volcano, June 1980 to October 1981 - degassing of a magma-hydrothermal system, J. Volcanol. Geotherm. Res., 28, 141-160.

Gerlach, T.M., K.A. McGee, A.J. Sutton and T. Elias (1998): Rates of volcanic $\mathrm{CO}_{2}$ degassing from airborne determinations of $\mathrm{SO}_{2}$, emission rates and plume $\mathrm{CO}_{2} / \mathrm{SO}_{2}$ : test study at Pu'u 'O'o cone, Kilauea volcano, Hawai`i, Geophys. Res. Lett., 25, 2675-2678.

Gianfrani, L., P. De Natale and G. De Natale (2000): Remote sensing of volcanic gases with a DFB-laser-based fiber spectrometer, Appl. Phys. (B), 70, 467-470.

Gianfrani, L., G. Gagliardi, M. van Burgel and E.R.TH. KERSTEL (2003): Isotope analysis of water by means of near-infrared duual-wavelength diode laser spectroscopy, Optics Express, 11 (13), 1566-1576.

Graf, H-F., B. Langmann and J. Feichter (1998): The contribution of Earth degassing to the atmospheric sulfur budget, Chem. Geol., 147, 131-145.

Hobbs, P.V., L.F. RadKe, J.H. Lyons, R.J. FereK, D.J. Coffman and T.J. Casadevall (1991): Airborne measurements of particle and gas emissions from the 1990 volcanic eruptions of Mount Redoubt, J. Geophys. Res., 96, 18735-18752.

Hoff, R.M. (1992): Differential $\mathrm{SO}_{2}$ column measurements of the Mt. Pinatubo volcanic plume, Geophys. Res. Lett., 19, 175-178.

Horrocks, L. (2001): Remote sensing of gas emissions from Masaya Volcano, Unpublished PhD. Thesis (The Open University).

Horrocks, L., M. Burton, P. Francis and C. OpPenheimer (1999): Stable gas plume composition measured by OP-FTIR spectroscopy at Masaya volcano, Nicaragua, 1998-1999, Geophys. Res. Lett., 26, 3497-3500.

Horrocks, L., C. OpPenheimer, M. Burton and H. DuFFELL (2003): Compositional variation in tropospheric volcanic gas plumes: evidence from ground-based remote sensing, in Volcanic Degassing, edited by C. OPPENheimer, D.M. Pyle and J. BARClay, Geol. Soc. London, Spec. Publ. 213, 349-369.

Love, S.P., F. Goff, D. Counce, C. Siebe and H. Delgado (1998): Passive infrared spectroscopy of the eruption plume at Popocatepetl volcano, Mexico, Nature, 396, 563-567.

Love, S.P., F. Goff, S.C. Schmidt, D. Counce, D. Pettit, B.W. Christenson and C. Siebe (2000): Passive In- 
frared Spectroscopic Remote Sensing of Volcanic Gases: Ground-based Studies at White Island and Ruapehu, New Zealand, and Popocatepetl, Mexico, in Remote Sensing of Active Volcanism, edited by $\mathrm{P}$ Mouginis-Mark, J. CrisP and J. Fink, Geophys. Monogr. 116, Am. Geophys. Union (Washington, D.C.), $117-138$

MALINCONICO, L.L. (1979): Fluctuations in $\mathrm{SO}_{2}$ emission during recent eruptions of Etna, Nature, 278, 43-45.

Mannino, D.M., S. Ruben, F.C. Holschum, T.C HolschuH, M.D. Wilson and T. HolschuH (1996): Emergency department visits and hospitalizations for respiratory disease on the island of Hawai $\mathrm{i}, 1981$ to 1991, Hawaii Med. J., 55 (3), 48-53.

McCormick, M.P., L.W. ThOMASON and C.R. TREPTE (1995): Atmospheric effects of the Mt. Pinatubo eruption, Nature, 373, 399-404.

MCGEE, K.A. (1992): The structure, dynamics and chemical composition of non-eruptive plumes from Mt. St Helens, 1980-1988, J. Volcanol. Geotherm. Res., 51, 269-282.

McGeE, K.A. and A.J. SutTon (1994): Eruptive activity at Mt. St. Helens, Washington, U.S.A. 1984-1988: a gas geochemistry perspective, Bull. Volcanol., 56, 435-446.

McGee, K.A., T.M. Gerlach, R. Kessler and M.P. DoUKAS (2000): Geochemical evidence for a magmatic $\mathrm{CO}_{2}$ degassing event at Mammoth Mountain, California, September-December 1997, J. Geophys. Res., 105, 8447-8456.

McGonigle A.J.S., C. Oppenheimer, B. Galle, T.A. MATHER and D. PYlE (2002): Walking traverse and scanning DOAS measurements of volcanic gas emission rates, Geophys. Res. Lett., 29 (20), 1985, doi: 10.1029/2002GL015827.

McGonigle, A.J.S. and C. Oppenheimer (2003): Optical sensing of volcanic gas and aerosol emissions, in $\mathrm{Vol}$ canic Degassing, edited by C. OPPENHEIMER, D.M. Pyle and J. Barclay, Geol. Soc. London, Spec. Publ., 213, 149-168.

MCGONigle, A.J.S., C OpPenheimer, B Galle, M. Edmonds, T. Caltabiano, G. Salerno M. Burton and T.A. MATHER (2003): Volcanic sulphur dioxide flux measurements at Etna, Vulcano and Stromboli obteined using an automated scanning static ultraviolet spectrometer, J. Geophys. Res., 108 (B9), 2455, doi: 10.1029/2002JB002261.

Meyer, P.L. and M.W. Sigrist (1990): Atmospheric monitoring using $\mathrm{CO}_{2}$-laser photoacoustic-spectroscopy and other techniques, Re. Sci. Instrum., 61, 1779-1807.

Millán, M.M. (1980): Remote sensing of Air Pollutants. A Study of some Atmospheric Scattering Effects, Atmos. Environ., 14, 1241-1253.

Millán, M.M. and R.M. Hoff (1978): Remote sensing of air pollutants by correlation spectroscopy-instrumental response characteristics, Atmos. Environ., 12, 853-864.

MoffAT, A.J. and M.M. MilláN (1971): The application of optical correlation techniques to the remote sensing of $\mathrm{SO}_{2}$ plumes using skylight, Atmos. Environ., 5, 677690.

Mori, T. and K. Notsu (1997): Remote CO, COS, CO $\mathrm{SO}_{2}$ and $\mathrm{HCl}$ detection and temperature estimation of volcanic gas, Geophys. Res. Lett., 24, 2047-2050.

Mori, T., K. Notsu, Y. TohJima and H. WAKITA (1993): Re- mote detection of $\mathrm{HCl}$ and $\mathrm{SO}_{2}$ in volcanic gas from Unzen volcano, Japan, Geophys. Res. Lett., 20, 1355-1358.

Mori, T., K. Notsu, Y. TOHJima, H. Wakita, P.M. Nuccio and F. ItAaliano (1995): Remote detection of fumarolic gas chemistry at Vulcano, Italy, using an FTinfrared spectral radiometer, Earth Planet. Sci. Lett., 134, 219-224.

NoguCHI, K. and H. KAMIYA (1963): Prediction of volcanic eruption by measuring the chemical composition and amounts of gases, Bull. Volcanol., 26, 367-378.

Notsu, K., T. Mori, G. Igarashi, Y. TohjIMA and H. WAKITA (1993): Infrared spectral radiometer: A new tool for remote measurement of $\mathrm{SO}_{2}$ of volcanic gas, Geochem. J., 27, 361-366.

Òdwyer, M., M.J. Padgett, A.J.S. McGonigle, C. OpPenHEIMER and S. INGUAGGIATO (2003): Real-time measurement of volcanic $\mathrm{H}_{2} \mathrm{~S}$ and $\mathrm{SO}_{2}$ concentrations by UV spectroscopy, Geophys. Res. Lett., 30 (12), 1652, doi: 10.1029/2003GL017246.

OPPENHEIMER, C. (1996): On the role of hydrothermal systems in the transfer of volcanic sulfur to the atmosphere, Geophys. Res. Lett., 23, 2057-2060.

OPPENHEIMER, C., P. Francis and J. STIX (1998a): Depletion rates of $\mathrm{SO}_{2}$ in tropospheric volcanic plumes, Geophys. Res. Lett., 25, 2671-2674.

OpPENHEIMER, C., P. FrANCIS and A. MACIEJEWSKI (1998b): Volcanic gas measurements by helicopter-borne fourier transform spectroscopy, Int. J. Remote Sensing, 19, 373-379.

Oppenheimer, C., P. Francis, M. Burton, A. Maciejewski and L. BOARDMAN (1998c): Remote measurement of volcanic gases by Fourier transform infrared spectroscopy, Appl. Phys. B, 67, 505-515.

Oppenheimer, C., P. Francis and A. Maciejewski (1998d): Spectroscopic observation of $\mathrm{HCl}$ degassing from Soufriere Hills volcano, Montserrat, Geophys. Res. Lett., 25, 3689-3692.

Oppenheimer, C., M. Edmonds, P. Francis and M.R. BurTON (2002): Variation in $\mathrm{HCl} / \mathrm{SO}_{2}$ gas ratios observed by Fourier transform spectroscopy at Soufrière Hills Volcano, Montserrat, in The eruption of Soufrière Hills Volcano, Montserrat, from 1995 to 1999, edited by T.H. DruitT and P. KokelaAr, Geol. Soc. London, Mem., 21, 621-639.

Oppenheimer, C., D.M. Pyle and J. Barclay (Editors) (2003): Volcanic Degassing, Geol. Soc. London, Spec. Publ. 213, pp. 420 .

Platt, U. (1994): Differential Optical Absorption Spectroscopy (DOAS), in Air Monitoring by Spectroscopic Techniques, edited by M.W. SIGRIST (John Wiley and Sons, New York), Chem. Anal. Ser., vol. 127, 2784.

Porter, J.N., K. Horton, P. Mouginis-Mark, B. Lienert, E. Lau, A.J. Sutton, T. Elias and C. Oppenheimer (2002): Sun photometer and lidar measurements of the plume from the Hawai'i Kilauea volcano Pu'u 'O'o vent: estimates of aerosol flux rates and $\mathrm{SO}_{2}$ lifetime, Geophys. Res. Lett., doi: 10.1029/2002GL014744.

RADKE, L.F. (1982): Sulphur and sulphate from Mt. Erebus, Nature, 299, 710-712.

Raga, G.B., G.L. KoK and D. Baumgardner (1999): Evidence for volcanic influence on Mexico City aerosols, Geophys. Res. Lett., 26, 1149-1152. 
Richter, D., M. ERdelyi, R.F. Curl, F.K. TitTel, C. OpPENHEIMER, H.J. DUfFELL and M. BuRTON (2002): Field measurement of volcanic gases using tunable diode laser based mid-infrared and Fourier transform infrared spectrometers, Opt. Lasers Eng., 37, 171-186.

Rose, W.I., R.L. ChuAn, W.F. Giggenbach, P.R. Kyle and R.B. SymONDS (1986): Rates of sulfur dioxide and particle emissions from White Island volcano, New Zealand, and an estimate of the total flux of major gaseous species, Bull. Volcanol., 48, 181-188.

Rose, W.I., G.J.S. Bluth, D.J. SchneIder, G.G.J. ERnst, C.M. Riley, L.J. HENDERSON and R.G. MCGIMSEY (2001): Observations of volcanic clouds in their first few days of atmospheric residence: the 1992 eruptions of Crater Peak, Mt. Spurr Volcano, Alaska, J. Geol., 109, 677-694.

Sparks, R.S.J., O. Melnik and A. Barmin, Dynamics of magma degassing, in Volcanic degassing, edited by $\mathrm{C}$. OpPenheimer, D.M. Pyle and J. BARClay, Geol. Soc. London, Spec. Publ. 213, 5-22.

Stevenson, D.S., C.E. Johnson, W.J. Collins and R.G. DERWENT (2003): The tropospheric sulphur cycle and the role of volcanic $\mathrm{SO}_{2}$, in Volcanic degassing, edited by C. Oppenheimer, D.M. Pyle and J. Barclay, Geol. Soc. London, Spec. Publ. 213, 295-305.

Stith, J.L., P.V. HobBs and L.F. RADKE (1978): Airborne particles and gas measurements in the emissions from six volcanoes, J. Geophys. Res., 83, 4009-4017.

Stix, J., W.H. Morrow, R. Nicholls and A. Charland (1996): Infrared remote sensing of CO and COS gas emitted by the Galeras volcano, Colombia, 8-10 January 1993, Can. J. Remote Sensing, 22, 297-304.

STOIBER, R.E. and A. JEPSEN (1973): Sulfur dioxide contribution to the atmosphere by volcanoes, Science, 182, 577-578

Stoiber, R.E., L.L. Malinconico and S.N. Williams (1983): Use of the correlation spectrometer at volcanoes, in Forecasting volcanic events, edited by $\mathrm{H}$. TAZIEFF and J.C. SABROUX (Elsevier, Amsterdam), 425444

Stoiber, R.E., S. Williams and B.J. Huebert (1986): Sulfur and halogen gases at Masaya caldera complex,
Nicaragua: total flux and varations with time, J. Geophys. Res., 91 (12), 215, 231.

Stoiber, R., S.N. Williams and B. Huebert (1987): Annual contribution of sulfur dioxide to the atmosphere by volcanoes, J. Volcanol. Geotherm. Res., 33, 1-8.

Symonds, R.B., W.I. Rose, G.J.S. Bluth and T.J. GERLACH (1994): Volcanic-gas studies: methods, results and applications, Rev. Mineral., 30, 1-66.

SyMONDS, R.B., Y. MizutANi and P.H. BRigGS (1996): Long-term geochemical surveillance of fumaroles at Showa-Shinzan dome, Usu Volcano, Japan, J. Volcanol. Geotherm. Res., 73, 177-211.

Symonds, R.B. T.M. GerLach and M.H. REED (2001): Magmatic gas scrubbing: implications for volcano monitoring, J. Volcanol. Geotherm. Res., 108, 303-341.

Thordarson, T., S. Self, N. Oskarsson and T. Hulsebosch (1996): Sulfur, chlorine and flourine degassing and atmospheric loading by the 1783-784 A.D. Laki (Skaftar fires) eruption in Iceland, Bull. Volcanol., 58, 205-225.

Wallace, P.J. (2001): Volcanic $\mathrm{SO}_{2}$ emissions and the abundance and distribution of exsolved gas in magma bodies, J. Volcanol. Geotherm. Res., 108, 85-106

Weibring, P., H. Edner, S. Svanberg, G. Cecchi, L. PanTANi, R. FERrara and T. CAltabiano (1998): Monitoring of volcanic sulphur dioxide emissions using differential absorption LIDAR (DIAL), Differential Optical Absorption Spectroscopy (DOAS) and correlation spectroscopy, Appl. Phys. (B), 64, 419-426.

Weidmann, D., C. Roller, F.K. Tittel, R.F. Curl, K. UeHara, C. Oppenheimer and P. De Natale (2003): Development of a $4.3 \mu \mathrm{m}$ quantum cascade laser based ${ }^{13} \mathrm{CO}_{2} /{ }^{12} \mathrm{CO}_{2}$ isotopic ratio sensor, in 2 nd International Symposium on Isotopomers, 4-7 November, Stresa, Italy, ISI 2003 (abstract).

Williams-Jones, G., K. Horton, H. Garbeil, A.J. Sutton and T. ELIAS (2003): Accurately measuring volcanic plume velocities - Cracking the gas flux dilemma, in Cities on Volcanoes, 14-18 July 2003, Hilo, Hawai i, vol. 3 (abstract volume), p. 141.

WITHAM, C.S. and C. OPPENHEIMER (2004): Mortality in England during the 1783/1784 Laki Craters eruption, Bull. Volcanol. (in review). 